\title{
Research on the Relationship between External Compensation Gap of Executives and Enterprise Innovation*
}

\author{
Yangyang Gu, Zhongjun Yang \\ School of Business, Nanjing Normal University, Nanjing, China \\ Email: 15150538799@163.com
}

How to cite this paper: Gu, Y.Y. and Yang, Z.J. (2018) Research on the Relationship between External Compensation Gap of Executives and Enterprise Innovation. Open Journal of Social Sciences, 6, 261-282.

https://doi.org/10.4236/jss.2018.68022

Received: August 9, 2018

Accepted: August 24, 2018

Published: August 27, 2018

Copyright ( 2018 by authors and Scientific Research Publishing Inc. This work is licensed under the Creative Commons Attribution International License (CC BY 4.0).

http://creativecommons.org/licenses/by/4.0/

\section{cc) (i) Open Access}

\begin{abstract}
How to use the pay contract to encourage executives to implement innovation activities has become an important issue to be solved by the theoretical and practical circles. Based on the data of Shanghai and Shenzhen A-share listed companies from 2006 to 2015, this paper examines the impact of external compensation gap on corporate innovation, and further discusses the contextual effects of executive talent and property rights. The study finds that the external compensation gap of executives has a positive effect on enterprise innovation. Moreover, the higher talent executives possess, the more obvious the external compensation gap will promote the innovation of enterprises. In addition, compared with state-owned enterprises, the external compensation gap of non-state-owned enterprise executives has a more significant effect on corporate innovation. This paper not only expands the economic consequences of the external compensation gap, but also provides inspiration for companies to adjust the compensation structure and encourage executives to promote enterprise innovation.
\end{abstract}

\section{Keywords}

Top Management Team, External Compensation Gap, Enterprise Innovation, Executive Talent, Property Rights

\section{Introduction}

Since the reform and opening up, although the Chinese economy has maintained a relatively rapid growth, the extensive economic development model has *Youth Fund Project of National Social Science Fund "Research on Financial Structure Optimization of the Yangtze River Economic Belt" (15CJY078). 
caused China's economic structure to be unbalanced and the sustainable development has insufficient stamina. With the gradual disappearance of China's demographic dividend advantage, Chinese companies are facing the dual pressures of high-end technology from emerging economies and cheap labor in other emerging economies [1]. Under this predicament, technological innovation has become an effective path and an inevitable choice for enterprises to transform their economic growth models, gain long-term competitive advantages, and break through the bottleneck of development. In 2015, the State Council promulgated "Opinions on Promoting Certain Policies and Measures for Mass Entrepreneurship and Innovation", clearly proposing the policy of "mass entrepreneurship and innovation", and regard innovation driving as the source of development, the way to enrich the people, the policy of fairness and the strategy of strengthening the country. Besides, in the report of the 19th National Congress of the Communist Party of China, President Jinping Xi once again emphasized the strategic policy of "strengthening the construction of the national innovation system... strengthening support for the innovation of small and medium-sized enterprises" as both an urgent and important part of the overall national economy and a strategic task; throughout the report, the word "innovation" appears as many as 60 times. It can be seen that cultivating and stimulating innovation is of great practical significance, and it is also the top priority of the survival of enterprises.

As we all know, enterprise innovation is a strategic decision centered on "people", and the top management team plays a key role in the planning and implementation of corporate innovation activities. At the same time, corporate innovation activities are also a strategic activity with high risk factors, long durations, and difficult to predict future returns. This will have a greater impact on the reputation and revenue of the top management team, which makes the management unwilling to lead. Also, it will carry out innovative activities with a high degree of risk. Agency Theory points out that the establishment of the interest-related mechanism through the compensation contract can achieve the synergy between management and shareholders. This not only compensates for the risk of executive positions, but also encourages executives to work hard to maximize the interests of shareholders. In view of this, how to design an effective and fair compensation contract, and then stimulate the executive team to implement innovative activities is an important issue that enterprises need to solve. It is worth emphasizing that in addition to the salary level, the external compensation structure ${ }^{1}$ (external compensation gap) is also an important part of the compensation contract. This is because the listed company executive compensation contract has obvious reference point effect [2], which will subconsciously compare with the horizontal company in the horizontal society, and then form a basic judgment on the current salary; and with the continuous im-

${ }^{1}$ Based on the current mainstream research results, this paper defines the external compensation gap as the ratio of the average salary of the senior management team to the average salary of the industry. 
provement of the marketization of pay and the increasing salary gap, the external compensation gap design of executives has become increasingly prominent in the compensation contract [3] [4], then its impact on corporate innovation activities is naturally worthy of in-depth study.

This paper takes the Shanghai-Shenzhen A-share listed company from 2006 to 2015 as research samples, based on the external compensation gap between the top management team and the senior executives, theoretically analyzes and empirically tests the relationship between external compensation gap and enterprise innovation. The research results show that the external compensation gap has a positive effect on enterprise innovation. Further, this paper examines the contextual effects of executive talent and property rights. The study also finds that the higher executive ability the executives possess, the more obvious the external compensation gap promotes the enterprise innovation. In addition, compared with state-owned enterprises, the external compensation gap of non-state-owned enterprise executives has a more significant effect on enterprise innovation.

The possible research contributions of this paper are as follows: 1) Most of the current research on the executive compensation gap is based on the internal salary gap of corporate executives, and the research on its external compensation gap is relatively insufficient. Moreover, the existing research is mainly limited to the analysis of the performance and executive separation framework to examine the economic consequences of the external compensation gap of the executive team [2] [4], and less on the research of enterprise innovation. Based on this, this paper introduces the research framework of enterprise innovation, focusing on the economic consequences of the external compensation gap, which not only complements the existing salary gap research, but also enriches the research content of enterprise innovation influence factors. 2) The existing research has not reached a consensus on the incentive effectiveness of the external compensation gap of executives [4] [5] [6]. Based on the framework of enterprise innovation, this paper analyzes the situational factors of executive compensation, which helps to clarify external compensation. The logic of the gap and the differences in the integration of previous studies. 3) The research in this paper has reference significance for enterprises to improve salary incentive policies, adjust compensation structure and guide innovation activities.

The research structure of this paper is as follows: the second part is the literature review and research hypothesis; the third part is the research designing; the fourth part is the empirical results and analysis; the fifth part is the research conclusion, research contribution, policy enlightenments and research inadequacies.

\section{Literature Reviewand Research Hypothesis}

\subsection{Literature Review}

The executive team is the most scarcely human capital of the company, how to motivate the executive team to work hard and ease the conflict of the agent has always been an important issue both on theoretical and practical circles. Among 
many incentive mechanisms, salary incentive is the most extensive form for current enterprises. The compensation gap designing is the most common explicit incentive method in the salary incentive mechanism, which reflects the social distribution characteristics to a certain extent. However, the current academic has no agreement on whether expanding the compensation gap between senior executives [4] [5] [6]. Specifically, some scholars mainly rely on the theory of tournaments as the theoretical basis, and believe that expanding compensation gap can play the role of incentive-oriented compensation [7] [8]. Lazear and Rosen (1981) pioneered the theory of tournaments, arguing that executives are competing players in the salary awards and position promotion tournaments. By setting a reasonable compensation gap, it helps to promote the hard work of executives, ease the conflict between principals and agents, and curb executives. Short-sighted behavior, which in turn plays a positive role in improving performance and improving performance [9]. Based on the tournament theory, Vieito (2012) believed that expanding compensation between CEO and non-CEO compensation is conducive to improving company performance [10]. Kong et al. (2017) found that the internal pay gap has a positive effect on the innovation output of enterprises, and thus supports the tournament theory. Li et al. (2014) examined the economic consequences of the external compensation gap based on the manager market theory similar to the tournament theory. The study found that the external compensation gap of non-state-owned executives has a positive effect on corporate performance [4].

At the same time, some scholars believe that the compensation gap will lead to unfair feelings, induce dissatisfaction, and breed negative psychological perceptions of exploitation and oppression, which is not conducive to the sustainable development of enterprises [2] [3]. For example, based on social comparative theory, Carpenter et al. (2004) argues that the compensation gap between CEOs and other executive team members is more likely to trigger dissatisfaction with low-paying executives, leading to a decline in corporate performance [11]. Trevor et al. (2012) pointed out that when executives find that the salary is not up to expectations, it will lead to psychological and unfair feelings, resulting in reduced willingness to cooperate and goal consistency, thereby damaging the organization's innovation activities and performance output [12]. Zhang (2007) found that there is a negative correlation between the compensation gap in China and the future performance of the organization, which supports the behavior theory to a certain extent [13]. Yang and Wang (2014) found that under the cultural tradition of "fairness" in China, the internal compensation gap of the company will induce negative incentives such as negative absenteeism and earnings management. Mei and Zhao (2016) took similar empirical evidence with China's A-share listed companies as samples [14].

Through the above literature review, we find that the research on the executive compensation gap has the following shortcomings: 1) The research on the existing compensation gap is mainly concerned with the economic consequences 
of the internal compensation gap both between the executives and between the executive and employee. However, as the manager market becomes more mature and the compensation gap among the peers continues to expend, the executives will subconsciously compare with the inter-bank executives to make horizontal compensation, and then decide the decision-making behavior. However, at present, the research on the economic consequences of the external compensation gap of executives is relatively poor. 2) Most of the research focuse on the relationship between compensation gap and enterprise performance. The research on the relationship between compensation gap and enterprise innovation is still insufficient. The relevant literature only pays attention to the relationship between internal compensation gap and enterprise innovation activities [8] [15], and the conclusion of the study did not reach an agreement. Then, the specific relationship between the external compensation gap of executives and corporate innovation activities remains to be seen. 3) The current research has not reached a consensus on the economic consequences of the executive compensation gap. In the face of unstable or even conflicting research conclusions, it is necessary to analyze the situational factors of the executive team's compensation difference. Through the investigation of the situational effect, it helps to clarify the logical chain of the interaction between the compensation gap and the enterprise's innovation activities, reveals the internal mechanism of the salary structure, and forms a further expansion of the executive team's salary research. In view of this, this paper takes the external compensation gap of executives as a starting point, analyzes the impact of the external compensation gap of the top management team on the innovation activities of the enterprise and further discusses the situational effects of executive talents and property rights to enrich and expand the executive compensation. Related research on the economic consequences of the gap.

\subsection{Research Hypothesis}

\subsubsection{External Compensation Gap of Executives and Enterprise Innovation}

As the degree of marketization of salaries and the turnover rate of managers continually increase, it is normal for corporate executives to conduct horizontal pay comparisons. Many studies show that the executive compensation contract of listed companies has obvious reference point effect. That is to say, the peer-reviewed salary benchmark is an important reference for the executive compensation process [16]. It is not difficult to speculate that the distance between executive compensation and peers' compensation benchmarks. The external compensation gap will affect the effectiveness of compensation incentives. Specifically, if the external compensation gap is large, it means that the executive compensation is higher than the top executive compensation level, which in turn will serve as a salary incentive. If the external compensation gap is small, it indicates that the top management gap is lower than the average salary level of the 
industry. The incentive effect of salary is not only not reflected, but will cause agency problems. In view of this, whether the external compensation gap will affect executive behavior and thus affect corporate innovation activities is an important issue to be addressed in this paper. This paper analyzes the internal relationship between executive compensation gap and corporate innovation activities from the following three levels.

Firstly, based on the manager market theory, in the mature manager market, the reputation mechanism can encourage executives to work hard and improve company performanceas an implicit contract [4]. The executive compensation level is a market equilibrium achieved by both the supply and demand sides after the manager can "bargain" [17], which will have an important impact on the reputation of the executives. Therefore, senior executives with lower salaries will work hard and be committed to achieving the company's innovation strategy. First of all, they can accumulate working experience and enhance innovation knowledge to cultivate human capital. Then, they can also accumulate reputation capital to change the weak position of compensation. In addition, in the face of fierce market competition, higher-paying executives will work hard to protect existing positions and high salaries, actively lead and participate in corporate innovation activities, in the hope of achieving corporate performance and personal reputation through innovative activities. It can be seen that increasing the external compensation gap can enhance the competition of executives for existing positions and salaries, thus generating a positive incentive effect, which is of great benefit to corporate innovation activities.

Secondly, based on the theory of social comparison, when executives find that their salaries are significantly lower than those of their peers, that is to say, the external compensation gap is too low. It will produce a kind of "black scorpion" mentality and psychological feelings of exploitation. Based on the imbalance of "paying more and less return", executives may negatively absent from work, ignore team goals, reduce teamwork, and take the initiative to express dissatisfaction [11] [14]. However, as the backbone of corporate innovation activities, executives' negative absenteeism or resignation will seriously undermine the organization's ability to innovate, restrict the enthusiasm of other employees to carry out innovative activities, and even lead to the stranding of innovative activities within the plan. Then, if the executive compensation level is continuously raised, the external compensation gap will increase, which will help reduce the unfairness of the top management due to low salary, thereby alleviating the disruptive effects of the top management team's negative absenteeism and personnel changes on the innovation activities of the enterprise. On the other hand, it helps to improve the sense of identity and satisfaction of the top management team [18], and then stimulate the enthusiasm and initiative of its leadership and innovation activities so that corporate innovation will be significantly improved.

Thirdly, based on the theory of self-attribution, executives will attribute the excessive external compensation gap to their own ability, and then derive the 
psychological bias of overconfidence [19]. Enterprise innovation is a high-risk, long-term investment activity, and overconfident executives tend to prefer risk in behavioral decision-making. They are more adventurous in corporate strategic layout, innovative research and development, and can withstand greater difficulties and risks. That will bring more opportunities for the company, which will help promote the implementation of enterprise innovation projects [20] [21].

Based on the analysis above, this paper believes that raising the external compensation gap can play a role on salary incentives, alleviate the unfair feeling of executives, and also strengthen the psychological perception of executives' overconfidence. Obviously, this will positively affect enterprise innovation activities. In this regard, this paper proposes the following assumption:

H1: The external compensation gap of executives is significantly positively correlated with enterprise innovation.

\subsubsection{Situational Effect of Executive Talent}

Based on the managerial signal hypothesis, the real power of executives is difficult to detect and quantify, and market participants need to perceive executive capabilities through company performance or other signals [22]. Many studies have shown that innovation activities can significantly affect business performance [23]. Therefore, leading and conducting innovation activities is an important and effective way for executives to demonstrate their talents to the outside manager market. Based on the manager market theory, the external compensation gap of executives can enhance competition and incentives. Then, in order to demonstrate their own capabilities, executives with higher talents have higher enthusiasm to participate in position and salary competition. At this time, they will work harder, increase innovation investment on a larger scale, and are willing to increase the investment of innovative venture capital. Force and endurance, which will promote the development of corporate innovation activities. On the contrary, if the executives are far lower than the peers' executive compensation, that is to say, the executive compensation gap is too small. The sense of injustice and oppressed by the high-caliber executives will be stronger, and the salary and talent will be dissatisfied. Emotions will not only lead to the negative completion of top management, reduce teamwork, but also induce the voluntary departure of senior executives, resulting in the invisible loss of valuable and scarce human capital, which will hinder the development and implementation of innovation activities [12].

Additionally, executives can bring a stronger positive feedback to executive self-importance and self-confidence along with excess compensation levels, which further strengthens executives' overconfidence and over-optimism. The so-called "high-tech daring", high-powered executives, driven by overconfidence, will be more diligent and eager to learn at work. Then more enthusiastic about difficult tasks and overcoming difficulties, and more likely to accept risky innovation projects. These will have a positive impact on corporate innovation. Based on the above discussion, this paper proposes the following assumption: 
$\mathrm{H} 2$ : The higher executive ability the executives possess, the more obvious the positive correlation between external compensation gap and enterprise innovation.

\subsubsection{Situational Effect of the Nature of Corporate Property Rights}

For enterprises with different property rights, the external compensation gap of executives is not the same. So this paper further examines the situational effects of different property rights. Specifically, due to the lack of sovereignty, inadequate governance structure, and inadequate information environment, state-owned enterprises have relatively weak corporate governance [24]. Moreover, the personnel appointment and dismissal rights of state-owned enterprise executives and the remuneration formulation rights are centralized and centralized to relevant departments of local governments at all levels. The selection and remuneration of state-owned enterprise executives are largely supervised and regulated by the government [25], which makes state-owned enterprise executives. There are institutional barriers to the development of mobility and compensation. It is not difficult to speculate that the situation of state-owned enterprises will lead to a blurred causal relationship between corporate performance and executive efforts, which greatly weakens the effectiveness of the development of compensation contracts based on executive capacity and business performance. At this time, the external compensation gap will greatly weaken the incentive effectiveness of state-owned enterprise executives so that it will be combined with the characteristics of long innovation cycle and high risk. Executives will be greatly tempted to work hard, actively lead and carry out enterprise innovation activities in order to obtain high salary.

In addition, state-owned enterprise executives not only face salary incentives, but also face promotion incentives at the administrative level. Especially under the influence of Chinese "official standard" traditional culture, political promotion is more important than economic interests to some extent [26], which will enable state-owned enterprise executives to pay more attention to meet their own decisions. Political demand for promotion at the executive level. Under the current situation of "mass entrepreneurship and innovation", innovation has become an important engine for the development of state-owned enterprises. At this time, even if the external compensation gap is too low, the executives will actively lead and carry out innovative activities in order to accumulate political resources and cultivate reputational capital. Therefore, promotion incentives have played a significant alternative role in salary incentives. On the other hand, non-state-owned enterprises have relatively perfect corporate governance and no administrative promotion incentives. Improving the company's performance is a more direct and effective way for senior executives to obtain high salaries and promotion. At this point, executives are more sensitive to external compensation gap and more responsive. At this time, the external compensation gap between executives and enterprise innovation activities will be more closely related. Based on this, this paper proposes the following assumption: 
H3: Compared with state-owned enterprises, the external compensation gap of non-state-owned enterprise executives is more effective in promoting enterprise innovation.

\section{Research Designing}

\subsection{Sample Selecting and Description}

This paper selects the data of Shanghai-Shenzhen A-share listed company from 2006 to 2015 as the primary sample. For ease of study, this paper processes and screens the initial samples based on the following principles: 1) Excluding listed companies in the financial industry; 2) excluding financial data and missing samples of corporate governance data; 3) excluding undisclosed pay data or a sample with a CEO compensation of zero. Through the above processing, the paper finally obtained 10,719 sample observations. The executive compensation data, corporate financial characteristics and corporate governance data covered in this paper are mainly from Guotaian database and Ruisi database. For suspicious data, we checked and corrected the company's financial statements and publicly disclosed information. In addition, in order to eliminate the possible impact of extreme values, the continuous variables involved in the $1 \%$ and $99 \%$ quantiles are tail-finished separately, and the processed data are used for descriptive statistics and regression analysis.

\subsection{Variable Definition}

1) External compensation gap. For the measurement of external compensation gap, this paper mainly adopts two measures. First, referring to the practice of Li et al. (2014) [4], Zhang and Guan (2016) [6], the ratio of the average salary of executives to the average salary of the industry is used as a surrogate for the external compensation gap (PGap 1). The average salary of executives among them is equal to the ratio of the total salary of executives to the number of executives who receive remuneration (the sum of executives minus the number of unpaid executives). The average salary of the industry is equal to all executive compensation in the same industry except the same year. Secondly, this paper refers to the method of Wang (2015) [5], using the standard deviation of the average salary of the executives and the average salary difference of the industry as the proxy variable of the externalcompensationy gap (PGap 2).

2) Innovation input (R\&D). Based on existing research, domestic and international indicators for measuring enterprise innovation mainly include $R \& D$ investment and patent quantity. However, because patent applications have time intervals and the quality of the results varies, this can interfere with the credibility of the research results. In view of this, this paper draws on Huang and Chen (2011) [27], Yang et al. (2017) [15], the enterprise innovation investment, that is to say, the ratio of enterprise $\mathrm{R} \& \mathrm{D}$ investment to the beginning of total assets, as a measure of the intensity of innovation activities.

3) Executive ability. This paper mainly refers to the practice of Demerjian et 
al. (2012) [28], using the DEA-TOBIT two-stage model to estimate the ability of executives. First, this paper uses data envelopment analysis to estimate company efficiency $(\theta)$. See model (1) for detail:

$$
\max _{v} \theta=\operatorname{Sales} /\left(v_{1} \operatorname{CoG} S+v_{2} S G \& A+v_{3} \text { Fixed }+v_{4} R \& D+v_{5} G W+v_{6} \text { Intan }\right)
$$

In the formula, operating income (Sales) is the output variable; operating cost (COGS), fixed assets (Fixed), sales and management expenses (SG\&A), goodwill (GW), R\&D investment (R\&D), intangible assets (Intan) for input variables. In addition, in order to eliminate the influence of company-level factors on the ability of executives to measure, based on the model (1) of this paper, the Tobit model can be used to estimate the executives. See model (2) for detail:

$$
\theta=\alpha+\beta_{1} \text { Size }+\beta_{2} M S+\beta_{3} F C F I+\beta_{4} \text { Age }+\beta_{5} H H I+\sum \lambda_{k} \text { Year }+\varepsilon
$$

In the formula, MS is the market share, FCFI is the free cash flow indicator, $\mathrm{HHI}$ is the Herfindahl index, and Age is the company's establishment time. The residual $\varepsilon$ is what is sought. The higher the value, the higher the executive can possess.

4) Property nature (State). The nature of the equity is a dummy variable. If the actual controller of the listed company is a state-owned enterprise of a state institution, institution, state-owned enterprise, or collective enterprise, the State value is 1 , otherwise it is 0 .

5) Control variables. In addition to the above variables, this paper also controls related variables such as corporate governance and financial characteristics, considering the missing variables leading to missing errors. In addition, this paper further introduces industry dummy variables and year dummy variables to control the impact of industry and year. The specific variable definitions are shown in Table 1.

\subsection{Model Designing}

In order to verify the impact of executive compensation gap on corporate innovation, this paper builds a model (3), specifically:

$$
R \& D=\alpha_{1}+\alpha_{2} \text { PGap }_{1}+\alpha_{3} \text { PGap }_{2}+\sum \alpha_{i} C V_{i}+\varepsilon
$$

where $C V_{\mathrm{i}}$ is the control variable mentioned above; $\varepsilon i$ represents the residual; other variables are as described above. In model (3), if the coefficient $\alpha_{2}$ and the coefficient $\alpha_{3}$ are significantly positive, then $\mathrm{H} 1$ is assumed to be verified.

In order to test hypothesis 2 , based on model (3), this paper adds executives and their interaction with the external pay gap of executives. See model (4) for detail:

$$
\begin{aligned}
R \& D= & \alpha_{1}+\alpha_{2} \mathrm{PGap}_{1}+\alpha_{3} \mathrm{PGap}_{2}+\alpha_{4} \mathrm{PGap}_{1} * \text { Ability } \\
& +\alpha_{5} \mathrm{PGap}_{2} * \text { Ability }+\alpha_{6} \text { Ability }+\sum \alpha_{i} C V_{i}+\varepsilon
\end{aligned}
$$

In model (4), if the coefficient of the interaction term $\alpha_{4}$ and $\alpha_{5}$ are significantly positive, then $\mathrm{H} 2$ is assumed to be verified.

Similarly, to test hypothesis 3, this paper builds a model (5) for testing, specifically: 
Table 1. Definition of main variables.

\begin{tabular}{|c|c|c|}
\hline Variable symbol & Variable meaning & Variable description \\
\hline $\mathrm{R} \& \mathrm{D}$ & $\begin{array}{l}\text { Innovation } \\
\text { investment }\end{array}$ & $\begin{array}{l}\text { The ratio of the company's } \mathrm{R} \& \mathrm{D} \text { investment to the total } \\
\text { assets at the beginning of the period, taking the percentage }\end{array}$ \\
\hline PGap1 & $\begin{array}{l}\text { Executive external } \\
\text { compensation gap }\end{array}$ & $\begin{array}{l}\text { The ratio of the average salary of executives } \\
\text { to the average salary of the industry }\end{array}$ \\
\hline PGap2 & $\begin{array}{l}\text { Executive external } \\
\text { compensation gap }\end{array}$ & $\begin{array}{l}\text { Standard deviation between the average salary of } \\
\text { executives and the average salary difference of the industry }\end{array}$ \\
\hline Ability & CEO talent & $\begin{array}{l}\text { It is obtained by fitting the DEA-TOBIT two-stage model. } \\
\text { See model (1) (2) for details. }\end{array}$ \\
\hline State & Company Type & $\begin{array}{l}\text { Virtual variable, if the actual controller is a state-owned } \\
\text { company, the value is } 1 \text {, otherwise } 0\end{array}$ \\
\hline Mgr & $\begin{array}{l}\text { Management } \\
\text { shareholding ratio }\end{array}$ & The ratio of executives holding company stocks \\
\hline Inst & $\begin{array}{c}\text { Institutional } \\
\text { shareholding ratio }\end{array}$ & The ratio of institutional investors holding company stocks \\
\hline Roa & Return on Assets & Company net profit/total assets \\
\hline TQ & Tobin Q & Company market value/asset replacement cost \\
\hline Lev & Debt level & Company debt/total assets \\
\hline Size & Company Size & Total assets of the company, take the natural logarithm \\
\hline H5 & Equity balance & Shareholding ratio of the top five shareholders \\
\hline Dual & Two positions & $\begin{array}{l}\text { If the } \mathrm{CEO} \text { also serves as the chairman, } \\
\text { the value is } 1 \text {, otherwise it is } 0 .\end{array}$ \\
\hline Age & Business age & $\begin{array}{l}\text { The number of years since the company } \\
\text { was listed, taking the natural logarithm }\end{array}$ \\
\hline Year & years & Year dummy variable \\
\hline IND & Industry & Industry dummy variable \\
\hline
\end{tabular}

In model (5), if the coefficient of the interaction term $\alpha_{4}$ and $\alpha_{5}$ are significantly negative, then $\mathrm{H} 3$ is assumed to be verified.

\section{Empirical Analysis}

\subsection{Descriptive Statistics}

Table 2 reports the distribution of innovation input intensity of enterprises in various industries. Among them, the information transmission, software and information technology services (I) and scientific research and technology services $(M)$ industries have the highest investment intensity of innovation, 5.973 and 3.726 respectively. This shows that the current high-tech emerging industry enterprises have higher innovation input intensity and put more emphasis on enterprise innovation, which is consistent with the actual situation. The lowest investment intensity of enterprise innovation is electricity, heat, gas and water 
Table 2. Distribution of innovation input intensity of enterprises in various industries.

\begin{tabular}{|c|c|c|c|c|c|c|}
\hline Industry & $\mathrm{N}$ & Mean & $\begin{array}{l}\text { Standard } \\
\text { deviation }\end{array}$ & Median & Minimum & Maximum \\
\hline $\begin{array}{l}\text { Agriculture, forestry, animal } \\
\text { husbandry, fishery (A) }\end{array}$ & 175 & 1.030 & 0.379 & 1.748 & 0.008 & 15.755 \\
\hline Mining industry (B) & 273 & 1.027 & 0.578 & 1.215 & 0.008 & 6.264 \\
\hline Manufacturing (C) & 8345 & 2.695 & 2.125 & 2.538 & 0.008 & 16.146 \\
\hline $\begin{array}{l}\text { Electricity, heat, gas and water } \\
\text { production and supply (D) }\end{array}$ & 162 & 0.259 & 0.055 & 0.547 & 0.008 & 4.501 \\
\hline Construction Industry (E) & 260 & 2.266 & 1.608 & 2.654 & 0.008 & 16.146 \\
\hline Wholesale and retail trade $(\mathrm{F})$ & 249 & 1.109 & 0.374 & 1.915 & 0.008 & 16.146 \\
\hline $\begin{array}{c}\text { Transportation, warehousing and } \\
\text { postal services }(G)\end{array}$ & 122 & 0.514 & 0.050 & 0.913 & 0.008 & 4.089 \\
\hline Accommodation and Catering $(\mathrm{H})$ & 16 & 1.402 & 0.185 & 3.537 & 0.017 & 13.915 \\
\hline $\begin{array}{c}\text { Information Transmission, Software } \\
\text { and Information Technology } \\
\text { Services (I) }\end{array}$ & 637 & 5.973 & 4.998 & 4.262 & 0.008 & 16.146 \\
\hline Real estate industry (K) & 107 & 0.871 & 0.071 & 2.994 & 0.008 & 16.146 \\
\hline Leasing and business services (L) & 37 & 0.970 & 0.206 & 1.524 & 0.008 & 6.316 \\
\hline $\begin{array}{c}\text { Scientific research and technical } \\
\text { services }(M)\end{array}$ & 66 & 3.726 & 2.089 & 3.573 & 0.157 & 15.172 \\
\hline $\begin{array}{l}\text { Water, Environment and Public } \\
\text { Facilities Management }(\mathrm{N})\end{array}$ & 46 & 1.564 & 1.345 & 2.536 & 0.008 & 16.146 \\
\hline Health and social work (Q) & 22 & 0.850 & 0.340 & 0.877 & 0.057 & 2.581 \\
\hline $\begin{array}{c}\text { Culture, sports and entertainment } \\
\text { (R) }\end{array}$ & 47 & 1.356 & 0.700 & 1.288 & 0.015 & 4.582 \\
\hline $\begin{array}{l}\text { Public Administration, Social } \\
\text { Security and Social Organizations (S) }\end{array}$ & 155 & 0.992 & 0.377 & 1.647 & 0.008 & 10.327 \\
\hline
\end{tabular}

production and supply (D) and transportation, warehousing and postal (G), only 0.259 and 0.514 respectively. This result further illustrates that there is a big difference in the intensity of innovation investment in different industries.

Table 3 reports the descriptive statistics of the main research variables in this paper. The mean of PGap1 is 1.191, which indicates that the average salary of listed company executives is 1.279 times of the industry average salary; the maximum multiple is 5.438 , and the minimum multiple is 0.256 . It can be seen that there are large differences in executive compensation levels of different companies. The maximum multiple is 5.438 and the minimum multiple is 0.256 . It can be seen that there are large differences in the executive compensation levels of different companies. In addition, the mean of State is 0.401, indicating that the proportion of state-owned listed companies in the sample companies is $40.1 \%$. The mean of Dual is 0.244 , indicating that $24.4 \%$ of the sample companies have the same chairmanship as the CEO. The mean of $\mathrm{H} 5$ is 0.541 , which means that the sample companies' top five shareholders have more than half of the shares. 
Table 3. Main variables' description statistics.

\begin{tabular}{ccccccc}
\hline Variable & $\mathrm{N}$ & Mean & $\begin{array}{c}\text { Standard } \\
\text { deviation }\end{array}$ & Median & Minimum & Maximum \\
\hline R\&D & 10719 & 2.653 & 2.791 & 1.974 & 0.008 & 16.150 \\
PGap1 & 10719 & 1.279 & 0.903 & 1.031 & 0.256 & 5.438 \\
PGap2 & 10719 & 0.000 & 0.859 & -0.235 & -1.056 & 4.000 \\
Ability & 10719 & -0.002 & 0.192 & 0.016 & -2.076 & 5.622 \\
State & 10719 & 0.401 & 0.490 & 0.000 & 0.000 & 1.000 \\
Roa & 10719 & 0.070 & 0.125 & 0.069 & -0.794 & 0.508 \\
Mgr & 10719 & 0.005 & 0.011 & 0.000 & 0.000 & 0.129 \\
Inr & 10719 & 0.172 & 0.180 & 0.110 & 0.000 & 0.813 \\
TQ & 10719 & 2.144 & 1.727 & 1.682 & 0.211 & 11.040 \\
Dual & 10719 & 0.244 & 0.429 & 0.000 & 0.000 & 1.000 \\
Size & 10719 & 21.600 & 1.164 & 21.430 & 18.830 & 25.360 \\
Lev & 10719 & 0.422 & 0.218 & 0.416 & 0.048 & 1.101 \\
Age & 10719 & 8.588 & 5.983 & 7.000 & 1.000 & 22.000 \\
H5 & 10719 & 0.541 & 0.159 & 0.547 & 0.186 & 1.000 \\
\hline
\end{tabular}

\subsection{Analysis of Regression Results}

Table 4 reports the results of multiple regression for Hypothesis 1. Model 1 shows the regression results of control variables on corporate innovation inputs. Model 2 shows that the regression coefficient of PGap1 is 0.572 and it reaches a level of significance of $1 \%$. Model 3 shows that the regression coefficient of PGap2 is 0.604 , also passing the $1 \%$ significance level. It is worthy to emphasize that after considering the external compensation gap, the goodness of fit of multiple regression results is greatly improved, indicating that the external compensation gap is indeed an important factor affecting the innovation investment of enterprises. In summary, the external compensation gap has a positive effect on corporate innovation investment. The reason is that the increase of external compensation can play the incentive role of the compensation contract. It can promote competition among the executives, improve the endurance of the executives to the innovation risk, and thus facilitate the development of enterprise innovation activities. Conversely, if the external compensation gap is too low, it will induce executives' dissatisfaction, which will greatly undermine executive leadership and the willingness to implement corporate innovation. Moreover, raising the compensation gap can strengthen executives' self-confidence, which makes executives more adventurous and brings more opportunities to the business. Undoubtedly, this trait is of great benefit to the company's innovative research and development. Thus, the Hypothesis 1 is verified.

Although model $3 R \& D$ takes the value of the next year, there may still be endogenous problems between the external compensation gap of executives and the innovation investment of enterprises. Firstly, the result of corporate 
Table 4. Executive external compensation gap and enterprise innovation investment.

\begin{tabular}{|c|c|c|c|c|c|}
\hline & \multicolumn{3}{|c|}{ OLS } & \multicolumn{2}{|c|}{ 2OLS } \\
\hline & Model 1 & Model 2 & Model 3 & Model 4 & Model 5 \\
\hline \multirow{2}{*}{ PGap1 } & & $0.572^{* * *}$ & & $3.028^{* * *}$ & \\
\hline & & $(15.80)$ & & (11.58) & \\
\hline \multirow{2}{*}{ PGap2 } & & & $0.604^{\star \star *}$ & & $3.320^{* * *}$ \\
\hline & & & $(15.76)$ & & $(11.37)$ \\
\hline \multirow{2}{*}{ Roa } & $1.674^{\star * *}$ & $0.982^{\star * *}$ & $1.018^{\star * *}$ & $-2.008^{* * *}$ & $-1.935^{\star * *}$ \\
\hline & $(5.76)$ & $(3.38)$ & $(3.52)$ & $(-4.31)$ & $(-4.16)$ \\
\hline \multirow{2}{*}{ Mgr } & 1.986 & 2.022 & 2.133 & 2.142 & 2.808 \\
\hline & $(0.89)$ & $(0.92)$ & $(0.98)$ & $(0.85)$ & $(1.10)$ \\
\hline \multirow{2}{*}{ Inr } & $0.880^{\star * *}$ & $0.597^{* * *}$ & $0.590^{* * *}$ & $-0.647^{* * *}$ & $-0.715^{\star * *}$ \\
\hline & $(5.90)$ & $(4.05)$ & $(4.01)$ & $(-2.80)$ & $(-2.99)$ \\
\hline \multirow{2}{*}{ TQ } & $0.209^{* * *}$ & $0.167^{\star * *}$ & $0.170^{* * *}$ & -0.013 & -0.007 \\
\hline & $(7.15)$ & $(5.73)$ & $(5.87)$ & $(-0.35)$ & $(-0.17)$ \\
\hline \multirow{2}{*}{ Dual } & 0.072 & 0.097 & 0.101 & $0.206^{\star * *}$ & $0.233^{\star * *}$ \\
\hline & $(1.11)$ & $(1.53)$ & $(1.60)$ & $(2.67)$ & $(2.99)$ \\
\hline \multirow{2}{*}{ Size } & $-0.175^{\star * *}$ & $-0.384^{\star \star *}$ & $-0.386^{* * *}$ & $-1.285^{\star * *}$ & $-1.331^{* * *}$ \\
\hline & $(-4.88)$ & $(-10.18)$ & $(-10.29)$ & $(-12.19)$ & $(-11.96)$ \\
\hline \multirow{2}{*}{ Lev } & $0.493^{\star * *}$ & $0.607^{\star * *}$ & $0.593^{\star * *}$ & $1.102^{* * *}$ & $1.044^{* * *}$ \\
\hline & $(2.64)$ & $(3.31)$ & $(3.24)$ & $(5.18)$ & $(4.92)$ \\
\hline \multirow{2}{*}{ Age } & $-0.014^{\star *}$ & $-0.018^{\star * \star}$ & $-0.018^{\star * *}$ & $-0.039^{\star * *}$ & $-0.038^{\star * \star}$ \\
\hline & $(-2.24)$ & $(-3.09)$ & $(-3.04)$ & $(-5.16)$ & $(-4.90)$ \\
\hline \multirow{2}{*}{ H5 } & 0.039 & 0.057 & 0.061 & 0.195 & 0.158 \\
\hline & $(0.21)$ & $(0.31)$ & $(0.34)$ & $(0.82)$ & $(0.65)$ \\
\hline \multirow{2}{*}{ Constant } & $3.126^{* * *}$ & $7.143^{* * *}$ & $7.923^{* * *}$ & $24.463^{\star * *}$ & $29.500^{* * *}$ \\
\hline & $(4.17)$ & $(9.18)$ & (10.04) & (11.97) & $(11.85)$ \\
\hline Kleibergen-Paaprk & & & & 201.653 & 188.039 \\
\hline LMstatistic & & & & {$[0.000]$} & {$[0.000]$} \\
\hline Kleibergen-Paaprk & & & & 213.520 & 197.377 \\
\hline Wald Fstatistic & & & & $\{16.38\}$ & $\{16.38\}$ \\
\hline $\mathrm{N}$ & 10,719 & 10,719 & 10,719 & 10,719 & 10,719 \\
\hline $\mathrm{R}^{2}$ & 0.179 & 0.205 & 0.205 & 0.269 & 0.322 \\
\hline
\end{tabular}

Note: The value in () is the T value; the value in [] is the $\mathrm{P}$ value of the corresponding statistic; the value in the \{\} is the Stock-Yogo test at the $10 \%$ level. ${ }^{*},{ }^{* *},{ }^{* *}$ indicate $10 \%, 5 \%$ and $1 \%$ significant levels respectively; the same below.

innovation investment may be the potential cause of the external compensation gap of executives. For example, enterprise innovation is a long-term strategic activity. If the staged results of executive leadership and implementation of inno- 
vation activities do not meet shareholder expectations. It will result in lower executive compensation levels than peers, resulting in a decrease in external compensation. It can be seen that the external compensation gap and corporate innovation activities are mutually causal and have endogenous problems. Secondly, in model 3, although the financial characteristic variables and corporate governance variables affecting the innovation investment of enterprises have been controlled as much as possible, there are still some variables that are difficult to measure and cannot be observed. At this time, missing the bias of the variables will also lead to deviations in the empirical results to some extent. In view of this, this paper selects the mean value of the compensation gap in the same region (the difference between executive compensation and the enterprises in the same region) as the instrumental variable for multiple regression. There are two reasons why this variable is selected as a tool variable: one of them is that when the board of directors sets the salary level for senior executives. It will not only consider the salary status of the senior executives, but also the existing salary levels in the same region. After all, the economic development and consumption levels of different regions are quite different. Therefore, the profile of the pay gap in the same region will naturally affect the pay gap of the sample company executives. The second reason is that the compensation gap in the same region does not affect the innovation investment activities of the sample companies. It can be seen that this variable can meet the requirements of instrument variable correlation and exogenous. It can be also seen that this variable can meet the requirements of instrument variable correlation and exogenous.

In order to further verify the validity of the instrumental variables, this paper performs a number of tests on the instrumental variables. The specific results are shown in Table 3, Model 4 and Model 5. Firstly, the Kleibergen-Paaprk LM statistic test rejected the null hypothesis of "insufficient tool variable identification" at the $1 \%$ significance level, indicating that the instrumental variables are related to the external pay gap. Secondly, the Kleibergen-Paaprk Wald F statistic is much larger than the $10 \%$ threshold of the Stock-Yogo weak identification test of 16.38 , indicating that the instrumental variable is more exogenous. In summary, the instrumental variables selected in this paper are scientific and effective. From Model 4 and Model 5, it can be seen that the external compensation gap is significantly positively correlated with the enterprise innovation investment, and both reached a confidence level of $1 \%$, which further supports the conclusion of this paper.

Table 5 reports the results of multiple regression for Hypothesis 2. The results show that from Model 1 to Model 4, executive talent can be significantly positively correlated with innovation investment at $1 \%$, indicating that executive talent can help promote innovation investment. It may result from "Technical people are daring". Outstanding executives tend to prefer challenging innovation projects to show that they are different. Model 2 shows that the regression coefficient of the PGap1 and Ability interaction terms is 0.379 , and the P value is less than $5 \%$. Model 4 shows that the regression coefficient of the PGap2 and Ability 
Table 5. Executive talent, external pay gap and enterprise innovation investment.

\begin{tabular}{|c|c|c|c|c|}
\hline & Model 1 & Model 2 & Model 3 & Model 4 \\
\hline Ability & $\begin{array}{c}2.246^{* * *} \\
(9.77)\end{array}$ & (5.59) & $\begin{array}{c}1.159^{* * *} \\
(5.03)\end{array}$ & $\begin{array}{c}1.281^{* * *} \\
(5.80)\end{array}$ \\
\hline PGap1 & $\begin{array}{l}0.549^{* * *} \\
(15.49)\end{array}$ & $\begin{array}{c}0.571^{\star * \star} \\
(16.37)\end{array}$ & & \\
\hline PGap2 & & & $\begin{array}{l}0.581^{* * *} \\
(15.38)\end{array}$ & $\begin{array}{c}0.605^{\star * *} \\
(16.40)\end{array}$ \\
\hline PGap $1^{\star}$ Ability & & $\begin{array}{l}0.379^{* *} \\
(1.99)\end{array}$ & & \\
\hline PGap $2 *$ Ability & & & & $\begin{array}{l}0.422^{* *} \\
(2.23)\end{array}$ \\
\hline Roa & $\begin{array}{l}0.694^{\star *} \\
(2.44)\end{array}$ & $\begin{array}{c}0.826^{* * *} \\
(2.89)\end{array}$ & $\begin{array}{c}0.873^{* * *} \\
(3.08)\end{array}$ & $\begin{array}{c}0.856^{\star * *} \\
(3.01)\end{array}$ \\
\hline Mgr & $\begin{array}{l}3.776^{\star} \\
(1.70)\end{array}$ & $\begin{array}{l}3.197 \\
(1.44)\end{array}$ & $\begin{array}{l}3.101 \\
(1.40)\end{array}$ & $\begin{array}{l}3.307 \\
(1.49)\end{array}$ \\
\hline Inr & $\begin{array}{c}0.728^{\star \star \star} \\
(4.94)\end{array}$ & $\begin{array}{c}0.674^{\star * *} \\
(4.57)\end{array}$ & $\begin{array}{c}0.660^{* * *} \\
(4.49)\end{array}$ & $\begin{array}{c}0.669^{* * \star} \\
(4.56)\end{array}$ \\
\hline TQ & $\begin{array}{c}0.128^{\star * *} \\
(4.44)\end{array}$ & $\begin{array}{c}0.145^{\star * *} \\
(5.01)\end{array}$ & $\begin{array}{c}0.147^{* * *} \\
(5.13)\end{array}$ & $\begin{array}{c}0.147^{\star * *} \\
(5.11)\end{array}$ \\
\hline Dual & $\begin{array}{l}0.084 \\
(1.32)\end{array}$ & $\begin{array}{l}0.084 \\
(1.32)\end{array}$ & $\begin{array}{l}0.089 \\
(1.40)\end{array}$ & $\begin{array}{l}0.086 \\
(1.37)\end{array}$ \\
\hline Size & $\begin{array}{l}-0.433^{\star * *} \\
(-11.58)\end{array}$ & $\begin{array}{l}-0.400^{* * *} \\
(-10.68)\end{array}$ & $\begin{array}{c}-0.398^{\star \star \star} \\
(-10.72)\end{array}$ & $\begin{array}{c}-0.404^{\star * *} \\
(-10.87)\end{array}$ \\
\hline Lev & $\begin{array}{l}0.329^{*} \\
(1.79)\end{array}$ & $\begin{array}{l}0.429^{* *} \\
(2.33)\end{array}$ & $\begin{array}{l}0.413^{* *} \\
(2.25)\end{array}$ & $\begin{array}{l}0.413^{* *} \\
(2.25)\end{array}$ \\
\hline Age & $\begin{array}{c}-0.016^{\star * *} \\
(-2.66)\end{array}$ & $\begin{array}{c}-0.018^{* * *} \\
(-2.95)\end{array}$ & $\begin{array}{c}-0.017^{\star * *} \\
(-2.90)\end{array}$ & $\begin{array}{c}-0.017^{* * *} \\
(-2.90)\end{array}$ \\
\hline H5 & $\begin{array}{l}-0.179 \\
(-0.98)\end{array}$ & $\begin{array}{l}-0.056 \\
(-0.30)\end{array}$ & $\begin{array}{l}-0.034 \\
(-0.18)\end{array}$ & $\begin{array}{l}-0.056 \\
(-0.30)\end{array}$ \\
\hline Constant & $\begin{array}{l}8.604^{\star * *} \\
(11.00)\end{array}$ & $\begin{array}{c}7.763^{* * *} \\
(9.89)\end{array}$ & $\begin{array}{c}8.445^{* * *} \\
(10.64)\end{array}$ & $\begin{array}{l}8.610^{* * *} \\
(10.82)\end{array}$ \\
\hline $\mathrm{N}$ & 10,719 & 10,719 & 10,719 & 10,719 \\
\hline $\mathrm{R}^{2}$ & 0.215 & 0.210 & 0.210 & 0.211 \\
\hline
\end{tabular}

interaction terms is 0.422 , and the $\mathrm{P}$ value is also less than $5 \%$. It can be seen that executive talent can positively adjust the positive correlation between external pay gap and enterprise innovation investment. As the hypothesis says, the higher the executive talent are, the more they prefer pay competition to show their tal- 
ents to the manager market. And executives can also strengthen their self-confidence. At this point, they will be more enthusiastic about innovation activities and increase their tolerance for innovation risks. In addition, outstanding executives will be more sensitive to unfair pay, and low external pay gaps will lead to more psychological dissatisfaction, which is not conducive to corporate innovation. It is not difficult to predict that the higher the executive ability, the more obvious the external salary gap will promote the innovation investment. Thus, hypothesis 2 is verified.

Table 6 reports the results of multiple regression for Hypothesis 2. From Model 1 to Model 4, the regression coefficient of State is significantly positive at $1 \%$, which indicates that the state-owned enterprises' innovation investment intensity is greater than that of non-state-owned enterprises. This may result from that state-owned enterprises are strong enough to bear and absorb the negative consequences of innovation failure. Therefore, they have more willing to carry out innovative activities. Both Model 2 and Model 4 show that both PGap $1^{\star}$ State and PGap $2 *$ State are significantly negatively correlated with corporate innovation investment and reach a level of $1 \%$ significance. This result indicates that the positive correlation between the external compensation gap of state-owned enterprise executives and innovation investment will be weaker than that of non-state-owned enterprises. This is due to the non-market-oriented executive selection, salary control and the pursuit of political promotion by state-owned enterprises, which has led to the sensitivity of state-owned executives to external compensation gap. At this time, the enthusiasm of state-owned enterprise executives to lead and carry out innovation activities based on external compensation gap will be reduced, which will lead to the impact of external compensation gap on innovation investment is lower than that of non-state-owned enterprises. Thus, hypothesis 3 is verified.

\subsection{Robustness Test}

In order to ensure the reliability of the research conclusions, a number of robustness tests are carried out. ${ }^{2}$ Firstly, the company's development of compensation contracts may not be random. Those individual characteristics of the company will affect the external compensation gap, which in turn affects the company's innovation investment and that may lead to missing variables and endogenous problems. In this regard, this paper uses the company's fixed effect regression method to test. The results showed that the regression coefficients of PGap1 (PGap2) were 0.260 (0.322), respectively, and both reached a significance level of $1 \%$. The empirical conclusions are highly consistent with the above findings. Secondly, this article replaces the proxy variable of the external compensation gap, which replaces the same industry executive compensation benchmark with the same region (province) compensation benchmark. And follow the original measurement and empirical steps to re-test, the original ${ }^{2}$ Considering the length of the paper, the following robustness test results are not included in the text. We can provide specific results if reviewers and readers need it. 
Table 6. Nature of property rights, external compensation gap and enterprise innovation investment.

\begin{tabular}{|c|c|c|c|c|}
\hline & Model 1 & Model 2 & Model 3 & Model 4 \\
\hline \multirow{2}{*}{ State } & $0.228^{* * *}$ & $0.235^{\star * *}$ & $0.229^{* * *}$ & $0.235^{\star * *}$ \\
\hline & $(3.45)$ & $(3.56)$ & $(3.48)$ & $(3.57)$ \\
\hline \multirow{2}{*}{ PGap1 } & $0.573^{* * *}$ & $0.584^{* * *}$ & & \\
\hline & (15.83) & (15.94) & & \\
\hline \multirow{2}{*}{ PGap2 } & & & $0.605^{\star * *}$ & $0.615^{\star * *}$ \\
\hline & & & $(15.80)$ & (15.88) \\
\hline \multirow{2}{*}{${\text { PGap }{ }^{\star} \text { State }}$} & & $-0.182^{* * *}$ & & \\
\hline & & $(-2.64)$ & & \\
\hline \multirow{2}{*}{ PGap2 ${ }^{*}$ State } & & & & $-0.189^{\star *}$ \\
\hline & & & & $(-2.57)$ \\
\hline \multirow{2}{*}{ Roa } & $1.008^{* * *}$ & $1.018^{* * *}$ & $1.043^{* * *}$ & $1.055^{* * *}$ \\
\hline & $(3.46)$ & $(3.50)$ & $(3.60)$ & $(3.64)$ \\
\hline \multirow{2}{*}{ Mgr } & 2.993 & 3.387 & 3.113 & 3.485 \\
\hline & $(1.37)$ & $(1.55)$ & $(1.43)$ & $(1.60)$ \\
\hline \multirow{2}{*}{ Inr } & $0.594^{* * *}$ & $0.586^{* * *}$ & $0.586^{* * *}$ & $0.577^{\star * *}$ \\
\hline & $(4.03)$ & $(3.96)$ & $(3.99)$ & $(3.92)$ \\
\hline \multirow{2}{*}{ TQ } & $0.171^{\star * *}$ & $0.171^{\star \star \star}$ & $0.174^{\star * *}$ & $0.173^{\star * *}$ \\
\hline & $(5.86)$ & $(5.86)$ & $(6.00)$ & $(6.00)$ \\
\hline \multirow{2}{*}{ Dual } & $0.124^{*}$ & $0.130^{\star *}$ & $0.128^{\star *}$ & $0.134^{\star *}$ \\
\hline & $(1.92)$ & $(2.02)$ & (1.99) & $(2.08)$ \\
\hline \multirow{2}{*}{ Size } & $-0.400^{* * *}$ & $-0.400^{* * *}$ & $-0.402^{\star * *}$ & $-0.401^{\star * *}$ \\
\hline & $(-10.43)$ & $(-10.43)$ & $(-10.54)$ & $(-10.53)$ \\
\hline \multirow{2}{*}{ Lev } & $0.587^{\star * *}$ & $0.570^{* * *}$ & $0.573^{* * *}$ & $0.556^{\star * *}$ \\
\hline & $(3.21)$ & $(3.12)$ & $(3.14)$ & $(3.05)$ \\
\hline \multirow{2}{*}{ Age } & $-0.025^{\star * *}$ & $-0.025^{\star * *}$ & $-0.025^{* * *}$ & $-0.025^{\star * *}$ \\
\hline & $(-4.01)$ & $(-4.02)$ & $(-3.98)$ & $(-3.97)$ \\
\hline \multirow{2}{*}{ H5 } & -0.016 & 0.012 & -0.013 & 0.016 \\
\hline & $(-0.09)$ & $(0.07)$ & $(-0.07)$ & $(0.09)$ \\
\hline \multirow{2}{*}{ Constant } & $7.439^{* * *}$ & $7.415^{* * *}$ & $8.225^{* * *}$ & $8.200^{* * *}$ \\
\hline & $(9.43)$ & (9.39) & (10.29) & $(10.25)$ \\
\hline $\mathrm{N}$ & 10,719 & 10,719 & 10,719 & 10,719 \\
\hline $\mathrm{R}^{2}$ & 0.206 & 0.206 & 0.206 & 0.207 \\
\hline
\end{tabular}

conclusion remains unchanged. Finally, this paper replaces the proxy variable of enterprise innovation investment. According to the practice of Ju et al. (2013) [29], using the ratio of the increment of intangible assets to the total assets at the beginning of the period to measure the innovation investment of enterprises, and re-testing, the empirical results are not significantly different. In general, the conclusions of this paper are robust and reliable. 


\section{Research Conclusions and Policy Recommendations}

As China's economic development enters the "new normal" period, enterprise technology innovation has become the main source of enterprises to enhance their core competitiveness and promote sustainable growth. In view of the high risk factor of enterprise innovation, how to construct a reasonable salary structure to promote executive leadership and implement innovation activities is an important issue to be solved by enterprises. In this regard, this paper takes the data of Shanghai-Shenzhen A-share listed company from 2006 to 2015 as a research sample, and systematically studies the relationship between external compensation gap and enterprise innovation with its internal mechanism. The study found that the external compensation gap is significantly positively related to corporate innovation and that stimulating external compensation gap can promote enterprise innovation. Further, the executive team can be more outstanding, and the external compensation gap is more obvious to the promotion of enterprise innovation. In addition, there is a difference in property rights between the external compensation gap and the impact of corporate innovation and that the promotion role of state-owned enterprises is weaker than that of non-state-owned enterprises.

Based on the above research, this paper may have the following marginal contributions: Firstly, most of the current research on the external compensation gap executives is based on the internal compensation gap of corporate executives, and the research on its external compensation gap is relatively insufficient. Moreover, the existing research is mainly limited to the analysis of the performance and executive separation framework to examine the economic consequences of the external compensation gap of the executive teams [2] [4], and less on the research of enterprise innovation. Based on this, this paper introduces the research framework of enterprise innovation, focusing on the economic consequences of the external compensation gap, which not only complements the existing compensation gap research, but also enriches the research content of enterprise innovation influence factors. Secondly, the existing research has not reached a consensus on the incentive effectiveness of the external compensation gap of executives [4] [5] [6]. Based on the framework of enterprise innovation, this paper analyzes the situational factors of executive compensation, which helps to clarify external compensation. The logic of the gap and the differences in the integration of previous studies. Thirdly, the research in this paper has reference significance for enterprises to improve compensation incentive policies, adjust compensation structure and guide innovation activities.

The conclusions of this paper have certain inspirational significance as follows:

1) When formulating and adjusting the compensation contract, the enterprises must consider the factors such as the performance of the executives, and also consider the impact of the peers' compensation benchmarks. If the external compensation structure of the company is too low, it will lead the executives to 
develop dissatisfaction and oppressed psychological perception, which will lead to the negative completion of the executives and even engage in opportunistic behavior, which in turn affects the effectiveness and efficiency of the innovation activities of the enterprise. Therefore, the board of directors should re-examine and adjust the external compensation gap of the company's executives to ensure that the compensation structure must balance competitiveness and fairness. At the same time, as far as possible, the external compensation gap of enterprises should be maintained at a high level, and the unreasonable use of external compensation gap will be avoided, which will hinder the innovation activities of enterprises.

2) Executive talent is the most valuable and scarce resource of the enterprise, and it is also the inexhaustible driving force for the enterprise to achieve sustainable development. The results of this paper indicate that corporate innovation is more sensitive to the external compensation gap of outstanding executives. In this regard, in order to effectively promote innovation activities, enterprises should attach great importance to the compensation structure of higher-level executives, moderately increase external compensation gap to attract and retain high-level talent, and to guide and motivate them to actively participate in corporate innovation activities.

3) This paper finds that state-owned enterprises lack market-oriented liquidity mechanism, and there are institutional obstacles in salary formulation, which makes the positive correlation between external compensation gap and enterprise innovation weak. In this regard, state-owned enterprises need to adhere to the market-oriented reform direction and increase the relationship between executive profit and loss and the company's development. By improving the sensitivity of salary performance to improve the incentive effectiveness of executive compensation contracts, and thus enhance the promotion of external compensation differences of executives to the innovation of state-owned enterprises.

However, there are some inadequacies in this study. First of all, the research sample of this paper is mainly limited to listed companies. The question whether the external compensation gap and enterprise innovation related relationship can represent all enterprises in China, especially the SMEs remains to be considered. Secondly, this paper mainly considers the monetary compensation of the executive team. Due to lack of access to the availability and completeness of the data, this paper does not consider the impact of the equity incentive compensation gap on executive decision-making behavior. Future research may consider combining other forms of compensation such as options to further examine the impact of external compensation gap on firm innovation. Finally, this paper only focuses on the impact of the external compensation gap of the executive team on corporate innovation, and does not consider the possible impact of external compensation gap. It is undeniable that employees are the main body of innovation in corporate innovation activities, especially the role of R\&D employees in innovation. However, due to the fact that listed companies did not disclose em- 
ployee compensation data, this paper could not conduct targeted research. This can be improved if future data is available.

\section{Conflicts of Interest}

The authors declare no conflicts of interest regarding the publication of this paper.

\section{References}

[1] Zhou, L.L., Li, T.T. and Li, J. (2017) Research on the Relationship between Executive Overconfidence and Innovation Sustainability. Science and Science and Technology Management, 38, 105-118.

[2] Xu, X.X. and Tan, W. (2014) Executive Compensation Contract, Reference Point Effect and Its Governance Effect: Theoretical Interpretation and Empirical Evidence Based on Behavioral Economics. Nankai Management Review, 17, 36-45.

[3] Faulkender, M. and Yang, J. (2007) Inside the Black Box: The Role and Composition of Compensation Peer Groups. Journal of Financial Economics, 96, 257-270. https://doi.org/10.1016/j.jfineco.2010.01.006

[4] Li, W.J., Yan, Y.Z. and Hu, Y.M. (2014) Does the External Pay Gap Motivate Executives?-Based on Empirical Research on the Market and Property Rights of Chinese Listed Companies' Managers. Nankai Management Review, 17, 24-35.

[5] Wang, H., Xiang, X.H. and Yin, F.Y. (2015) Executive Power, External Pay Gap and Company Performance Forecast Behavior-Based on Empirical Evidence of China's Securities Market. Journal of Huazhong University of Science and Technology (Social Science Edition), 6, 92-104.

[6] Zhang, R.H. and Guan, K.L. (2016) Will the Executive Pay Gap Induce an Occupational Duty Crime?-Evidence from Chinese Listed Companies. Accounting Research, 9, 47-54.

[7] Faleye, O., Reis, E. and Venkateswaran, A. (2013) The Determinants and Effects of CEO_Employee Pay Ratios. Journal of Banking and Finance, 37, 3258-3272. https://doi.org/10.1016/j.jbankfin.2013.03.003

[8] Kong, D.M, Xu, Y.L. and Kong G.W. (2017) Internal PayGap and Innovation in the Enterprise. Economic Research, 10, 144-157.

[9] Lazear, E. (1981) Rank-Order Tournaments as Optimal Labor Contracts. Journal of Political Economy, 89, 841-864. https://doi.org/10.1086/261010

[10] Vieito, J.P.T. (2012) Gender, Top Management Compensation Gap and Company Performance: Tournament versus Behavioral Theory. Corporate Governance an International Review, 20, 46-63. https://doi.org/10.1111/j.1467-8683.2011.00878.x

[11] Carpenter, M.A., Geletkanycz, M.A., and Sanders, W.G. (2004) Upper Echelons Research Revisited: Antecedents, Elements and Consequences of Top Management Team Composition. Journal of Management, 30, 749-778.

https://doi.org/10.1016/j.jm.2004.06.001

[12] Trevor, C.O., Reilly, G., and Gerhart, B. (2012) Reconsidering Pay Dispersion's Effect on the Performance of Interdependent Work: Reconciling Sorting and Pay Inequality. Academy of Management Journal, 55, 585-610. https://doi.org/10.5465/amj.2006.0127

[13] Zhang, Z.T. (2007) Senior Management Team Collaboration Needs, Pay Gap and Corporate Performance: Perspective of Competition Theory. Nankai Management 
Review, 10, 4-11.

[14] Yang, Z.Q. and Wang, H. (2014) Internal Compensation Gap, Equity Concentration and Earnings Management Behavior-Based on Comparative Analysis of Compensation between Executive Teams and Executives and Employees. Accounting Research, 6, 57-65.

[15] Yang, W., He, X.G., Zhu, L. and Wang, B.L. (2017) Vertical Pay Gap and the Innovative Spirit of New Ventures. Financial Research, 43, 32-44.

[16] Bizjak, J.M., Lemmon, M.L. and Naveen, L. (2008) Does the Use of Peer Groups Contribute to Higher Pay and Less Efficient Compensation? Journal of Financial Economics, 90, 152-168. https://doi.org/10.1016/j.jfineco.2007.08.007

[17] Gabaix, X. and Landier, A. (2008) Why Has CEO Pay Increased So Much? Quarterly Journal of Economics, 123, 49-100. https://doi.org/10.1162/qjec.2008.123.1.49

[18] Yan, S.P., Bi, X.F. and Li, X. (2017) Does the Pay Gap Inspire Innovation in High-Tech Enterprises? Scientific Decision-Making, 6, 1-28.

[19] Wen, F. and Tang, S.X. (2012) Salary Incentives and Managers' Overconfidence-Based on the Study of Pay Behavior Views. Financial Research, 9, 48-58.

[20] Goel, A.M. and Thakor, A.V. (2008) Overconfidence, CEO Selection and Corporate Governance. Journal of Finance, 63, 2737-2784. https://doi.org/10.1111/j.1540-6261.2008.01412.x

[21] Peng, S. (2014) Managers Are Overconfident, Innovative and Corporate. Xiamen University, Xiamen.

[22] Cheng, X.S., Liu, J.M. and Chen, J.H. (2015) Talent Signal or Compensation Defense: Excess Compensation and Strategic Information Disclosure. Financial Research, 12, 146-161.

[23] Fagerberg, J. (2005) Innovation and Catching-Up: Why Some Countries Succeed and Others Do Not. Georgia Institute of Technology.

[24] Shleifer, A. and Vishny, R.W. (1997) The Limits of Arbitrage. Journal of Finance, 52, 35-55. https://doi.org/10.1111/j.1540-6261.1997.tb03807.x

[25] Mei, C. and Zhao, X.J. (2016) Salary Ddifferences, Executive Turnover and Corporate Performance. Foreign Economics and Management, 38, 19-35.

[26] Wang, Z., Fu, G.Q., Huang, D.Y. and Wang, J.F. (2014) Research on the Relationship between "Political Promotion" and "On-the-Job Consumption" of CEOs of State-Owned Enterprises. Management World, 5, 157-171.

[27] Huang, J. and Chen, X. (2011) Group Management and Enterprise R\&D Investment-Analysis Based on Knowledge Spillover and Internal Capital Market Perspective. Economic Research, No. 6, 80-92.

[28] Demerjian, P., Lev, B. and Mcvay, S. (2012) Quantifying Managerial Ability: A New Measure and Validity Tests. Management Science, 58, 1229-1248. https://doi.org/10.1287/mnsc.1110.1487

[29] Ju, X.S., Lu, Y.H. and Yi, Y.H. (2013) Financing Constraints, Working Capital Management and Enterprise Innovation Sustainability. Economic Research, 1, 4-16. 